\title{
Phenylketonuria: A Reassessment of Mass Infant Screening by Napkin Test*
}

\author{
J. B. P. STEPHENSON, $\dagger$ M.A., B.M., M.R.C.P., B.C.H. ; M. S. MCBEAN, $\ddagger$ M.B., B.S.
}

Brit. med. F., 1967, 3, 582

Most local health authorities in Great Britain have used the Phenistix test on wet napkins or diapers (napkin-Phenistix test) to screen all young infants for phenylketonuria (Centerwall et al., 1963). This test is a sensitive and reliable method of detecting phenylpyruvic aciduria (Gibbs and Woolf, 1959; Woolf, 1963), which is an early sign of true phenylketonuria (Allen et al., 1964 ; Berry and Wright, 1967). Some practical difficulties have been emphasized by Hudson and Ireland (1959), but information is lacking on the effectiveness of the napkin test in mass detection programmes. In the Birmingham screening survey (Boyd, 1961) one case was found out of 18,981 tested, which was thought to be adequate, assuming a regional incidence of one in 20,000 births. In Edinburgh a similar incidence was predicted, but the one expected case was missed (Farquhar et al., 1962).

\section{Present Study}

With the assistance of the seven local health authorities involved we have investigated 15 true phenylketonurics

TABLB I.-Phenylketonurics Born into Napkin-Phenistix Screening

\begin{tabular}{|c|c|c|c|c|c|}
\hline \multicolumn{5}{|c|}{ Phenistix Result } & \multirow{4}{*}{$\begin{array}{l}\text { No. of Patients } \\
4 \text { (youngest aged } 53 \text { days) } \\
2 \text { ( } 1 \text { aged } 9 \text { months; } 1 \text {.Q. } 47) \\
6 \text { (2 tested under } 3 \text { weeks only: } 1 \text { in } \\
\text { hospital aged } 6 \text { weeks) } \\
3 \text { ( } 1 \text { ?negative aged } 42 \text { days: no record } \\
\text { made. } 1 \text { only at home aged } 5-11 \text { weeks) }\end{array}$} \\
\hline Positive & $\left\{\begin{array}{l}\text { Under } \\
\text { Over } 3\end{array}\right.$ & $\begin{array}{l}\text { mon } \\
\text { iontl }\end{array}$ & old & 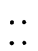 & \\
\hline Negative. & $\cdot \quad \cdots$ & . & $\cdots$ & * & \\
\hline Not tested & .. & . & . & .. & \\
\hline Total & . & . & . & .. & 15 \\
\hline
\end{tabular}

TABLE II.-Results of 16 Napkin-Phenistix Tests on 12 Phenylketonurics, Related to Age of Testing

\begin{tabular}{c|c|c|c}
\hline & \multicolumn{3}{|c}{ Results } \\
\hline $\begin{array}{c}\text { Age } \\
\text { (weeks) }\end{array}$ & $\begin{array}{c}\text { No. of } \\
\text { Tests }\end{array}$ & Positive & Negative \\
\hline $1-3$ & 6 & $\overline{6}$ & 6 \\
$5-10$ & 4 & 5 & 3 \\
$>10$ & 6 & 5 & 1 \\
\hline
\end{tabular}

(Stephenson and McBean, 1967) who were born when screening programmes were in operation, between 1960 and 1965. Siblings of previously known phenylketonurics have been excluded from the study. The dates and results of napkin tests were determined from the Child Welfare record cards. The details are given in Table I.

- From the University Department of Child Health and the Royal Hospital for Sick Children, Glasgow.

† Registrar in Medical Paediatrics, Royal Hospital for Sick Children, Glasgow C.4

‡ Research Assistant, Royal Hospital for Sick Children, Glasgow C.4.
It is apparent from Table II that all napkin-Phenistix tests in the first three weeks of life were negative, but much more serious is the fact that even in the age group 5-10 weeks only one of four tests was positive.

When the four patients with negative napkin-Phenistix tests over the age of 5 weeks were finally diagnosed they were all obviously affected, and in each case the urine reacted strongly with ferric chloride. Table III shows the serum phenylalanine levels and I.Q. at the time of diagnosis.

TABI.B III.-Missed Phenylketonurics : Finding on Diagnosis

\begin{tabular}{l|c|c|c}
\hline $\begin{array}{c}\text { Age at Negative } \\
\text { Napkin Test }\end{array}$ & $\begin{array}{c}\text { Age at Diagnosis } \\
\text { (months) }\end{array}$ & $\begin{array}{c}\text { Serum } \\
\text { Phenylalanine } \\
\text { (mg./100 ml.)* }\end{array}$ & I.Q. \\
\hline 5 weeks 2 days & 9 & 26 & 43 (Cattell) \\
7 "1 day & 3 & 70 & 51 (Griffiths) \\
9 mon'3 days & 25 & 42 & $46 \%$ ", \\
\hline
\end{tabular}

- La Du and Michael (1960).

\section{Conclusions}

This investigation shows that the napkin-Phenistix test in a mass screening programme is not an efficient tool for the early detection of classical phenylketonuria. Even the detection rate of $27 \%$ under the age of 3 months is probably optimistic, because cases missed towards the end of the period-for example, 1965-may not yet be obviously retarded, and most of the children at risk have not entered school.

A great deal of enthusiasm, hard work, and organizational skill have gone into the execution of these mass screening programmes, but the time has come for such energies to be directed towards more efficient methods of detection.

This study would have been impossible without the co-operation of the medical officers of the Health Departments of Airdrie, Clackmannan, Clydebank, Falkirk, Glasgow, Motherwell, Paisley, Ealing, and Londonderry. We thank Professor J. H. Hutchison and Dr. R. A. Shanks for encouragement and criticism.

\section{REFERENCES}

Allen, R. J., Heffelfinger, J. C., Masutti, M. D., and Tsau, M. U. (1964).

Pedratrics, 33. 512.

Boyd, M. M. M. (1961). Brit. med. T. 1, 771.

Centerwall, W. R., Berry, H. K., and Woolf, L. I. (1963). In Phenylketonuria, edited by F. L. Lyman, p. 117. Springfield, Illinois. Farquhar, J. W, Kansas, E. T.. and Tait, H. P. (1962). Lancet, 2, 498. Gibbs, N. K., and Woolf, L. I. (1959). Brit. med. 7., 2, 532.

Hudson, F. P., and Ireland, J. (1959). Ibid., 2, 885.

La Du, B. N., and Michael, P. J. (1960). F. Lab. clin. Med., 55, 491.

Shephenson, J. B. P., and McBean, M. S. (1967). Brit. med. Ұ., 3, 579.

Woolf, L. I (1963). In Phenylketonuria, edited by F. L. Lyman, p. 251. Springfield, Illinois. 